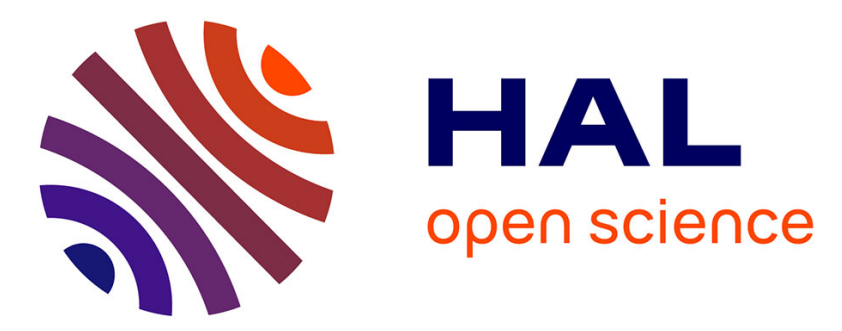

\title{
Time-to-cure and cure proportion in solid cancers in France. A population based study
}

Gaëlle Romain, Olayidé Boussari, Nadine Bossard, Laurent Remontet, Anne-Marie Bouvier, Morgane Mounier, Jean Iwaz, Marc Colonna, Valérie Jooste

\section{To cite this version:}

Gaëlle Romain, Olayidé Boussari, Nadine Bossard, Laurent Remontet, Anne-Marie Bouvier, et al.. Time-to-cure and cure proportion in solid cancers in France. A population based study. Cancer Epidemiology, 2019, 60, pp.93 - 101. 10.1016/j.canep.2019.02.006 . hal-03485644

\section{HAL Id: hal-03485644 https://hal.science/hal-03485644}

Submitted on 20 Dec 2021

HAL is a multi-disciplinary open access archive for the deposit and dissemination of scientific research documents, whether they are published or not. The documents may come from teaching and research institutions in France or abroad, or from public or private research centers.
L'archive ouverte pluridisciplinaire HAL, est destinée au dépôt et à la diffusion de documents scientifiques de niveau recherche, publiés ou non, émanant des établissements d'enseignement et de recherche français ou étrangers, des laboratoires publics ou privés.

\section{(c) (1) $\$$}

Distributed under a Creative Commons Attribution - NonCommercial| 4.0 International 
Time-to-cure and cure proportion in solid cancers in France.

\section{A population based study.}

Gaëlle ROMAIN ${ }^{1,2,3,4}$, Olayidé BOUSSARI ${ }^{1,3,4,5}$, Nadine BOSSARD ${ }^{6,7,8,9}$, Laurent REMONTET ${ }^{6,7,8,9}$, Anne-Marie BOUVIER ${ }^{1,2,3,4},{ }^{1}$ Morgane MOUNIER ${ }^{2,3,4,10}$, Jean IWAZ 6,7,8,9, Marc COLONNA ${ }^{11}$, Valérie JOOSTE ${ }^{1,2,3,4}$; French Network of Cancer Registries (FRANCIM)

${ }^{1}$ Registre Bourguignon des cancers digestifs, Dijon, France

${ }^{2}$ Centre Hospitalier Universitaire de Dijon Bourgogne, Dijon, France

${ }^{3}$ INSERM, LNC UMR1231, Dijon, France

${ }^{4}$ Université de Bourgogne Franche-Comté, Dijon, France ;

${ }^{5}$ Laboratoire d'Excellence LabEX LipSTIC, ANR-11-LABX-0021, Dijon, France

${ }^{6}$ Hospices Civils de Lyon, Service de Biostatistique-Bioinformatique, Lyon, France

${ }^{7}$ Université de Lyon, Lyon, France

${ }^{8}$ Université Lyon 1, Villeurbanne, France

${ }^{9}$ CNRS UMR 5558, Laboratoire de Biométrie et Biologie Évolutive, Équipe Biostatistique Santé, Pierre-Bénite, France

${ }^{10}$ Registre des Hémopathies Malignes de Côte d'Or, Dijon, France

${ }^{11}$ Registre du Cancer de l'Isère, Centre Hospitalier Universitaire Grenoble-Alpes, Grenoble, France

\section{Corresponding author:}

Dr Valérie Jooste

Registre Bourguignon des cancers digestifs

UFR des sciences de santé, BP 87900

F-21079 Dijon CEDEX

France

Tel: +33 380393325 ; Fax: +33 380668251

E-mail: valerie.jooste@u-bourgogne.fr

Word count: 3,181 


\begin{abstract}
Background: In cancer care, the cure proportion (P) and time-to-cure (TTC) are important indicators for practitioners, patients, and healthcare policy makers. The recent definition of TTC as the time at which the probability of belonging to the cured group reaches $95 \%$ was used for the first time.
\end{abstract}

Methods: The data stem from the common database of French cancer registries including 335,358 solid tumours diagnosed between 1995 and 2009 at 27 sites. P and TTC were estimated through a flexible parametric net survival cure model for each cancer site, sex, and age at diagnosis with acceptable assumption of cure (excess mortality rate $\leq 0.05$ ).

Results: TTC was $\leq 5$ years and $\mathrm{P}$ was $>80 \%$ for skin melanoma and thyroid and testis cancers. It was 0 for testis cancer in men $<55$ and for thyroid cancer in men $<45$ and women $<65$. TTC was between 5 and 10 years for all digestive cancers except small intestine and all gynaecologic cancers except breast. It was $\geq 10$ years in prostate, breast, and urinary tract. The range of $\mathrm{P}$ according to age and sex was $37-79 \%$ for urinary tract $72-88 \%$ for prostate and breast, 4-16\% for pancreatic and 47-62\% for colorectal cancer.

Conclusion: Time-to-cure was estimated for the first time from a large national database and individual probabilities of cure. It was 0 in the younger patients with testis or thyroid cancer and $<12$ years in most cancer sites. These results should help improve access to credit and insurance for patients still alive past the estimated TTCs.

Keywords: statistical cure, time-to-cure, cure proportion, cure models, population based cancer registry, survival, epidemiology. 


\section{Introduction}

Of the three million people living in France with a personal history of cancer [1], a large proportion will not die from cancer. Although clinical cure is difficult to evaluate, especially in large cohorts, statistical cure can be defined as the absence of death due to cancer. The proportion that will not die from cancer is therefore the cure proportion $\mathrm{P}$ (or cure fraction). $\mathrm{P}$ can be estimated using net survival cure models and cancer registry data. Up to now, cure models provided estimations of the cure proportion and of the whole net survival of fatal cases $[2,3]$. The time-to-cure is also of great interest for public health deciders, epidemiologists, physicians, and patients. Only one previous study has provided estimations of the time-to-cure using conditional net survival applied to Italian cancer registries data [4]. Boussari et al. have recently proposed a more intuitive definition of the time-to-cure, as the delay TTC after which the probability of belonging to the cured group (estimated from the cure proportion and the net survival) reaches a high pre-defined value $[5]$.

In cancer studies, net survival is defined as the survival that would be observed if cancer were the only cause of death $[6,7]$. In large cohorts, the causes of death are not reliable; net survival is thus estimated using the excess mortality rate; i.e., the difference between the mortality rate observed in the cohort and the mortality rate expected in the general population that shares same socio-demographic characteristics [8,9]. When cure occurs, the excess mortality rate tends to zero; thus the net survival tends to the cure proportion [10]. The ratio between the cure proportion and the net survival is then the probability of belonging to the cured group $[5,11]$.

As a follow-up of our previous study which proposed TTC as a definition of the time-to-cure and using net survival cure models, the aim of the present study was to estimate the cure proportion and the time-to-cure in France regarding solid cancer sites for which the assumption of statistical cure was deemed acceptable. 


\section{Patients and Methods}

\subsection{Patients and main characteristics}

The study concerned all solid tumours diagnosed January 1, 1995 to December 31, 2009 in patients aged 15 to 74 years $(\mathrm{N}=335,358)$ and recorded by FRANCIM (the French network of cancer registries). FRANCIM data are checked for quality and completeness every four years by an independent audit committee (Comité d'Évaluation des Registres).

The considered cancer sites adopted the definitions of the International Classification of Diseases for Oncology, $3^{\text {rd }}$ revision (ICD-O-3)[12]. To ensure sufficient numbers of events to fit the parametric flexible model that uses restricted cubic splines with potentially up to 20 parameters (see Methods section), cancer sites with $<500$ cases and $<200$ deaths were excluded from the analysis. These were choroid, lip, salivary gland cancers, malignant neoplasm without specification of site as well as penis cancer in men and bone, nasal cavity, pleural mesothelioma and urinary tract cancers in women. These exclusions left 27 sites and 7 subsites for analysis.

As in previous FRANCIM studies [13], age at diagnosis was considered in four groups: $<45,45-54,55-64$, and 65-74 years. In 11 sites in men and 7 in women, the first two age groups had to be pooled because the number of cases was $<50$. Patient vital status was followed over 15 years after diagnosis or up to June 30, 2013. The proportion of deceased patients was $49 \%$ and the proportion of patients lost to follow-up was $2.6 \%$ (Table 1 in men and Table 2 in women).

\subsection{Methods}

\section{Estimation of net survival without assumption of cure}

For each sex and Département (French administrative area), the expected mortality rates were derived from the general population mortality rates provided by the Institut National de la Statistique et des Études Économiques (INSEE). These rates were "observed" 
mortality rates (obtained simply by dividing the observed number of death by the corresponding number of person-years). These observed rates presented random (Poissonian) variation and were thus smoothed in order to obtain their expected values. This work was done by the Biostatistical unit of the Hospices Civils de Lyon, using mgcv package of R software.

The net survival was estimated using a flexible parametric model on the log cumulative excess hazard scale with restricted cubic spline function of log time $[14,15]$. In this model, the log cumulative excess hazard is forced to be linear beyond the boundary knots. The splines had four internal knots located at the $25^{\text {th }}, 50^{\text {th }}, 75^{\text {th }}$, and $95^{\text {th }}$ percentiles of the observed death times and boundary knots located at the $1^{\text {st }}$ percentile of the observed death times and at 17 years. A separate model was fitted for each cancer site and sex. Age was included in the model as a categorical variable. Its time-dependent effect was added for each category (splines with two internal knots located at the $33^{\text {rd }}$ and $67^{\text {th }}$ percentiles of the observed death times) and evaluated with a likelihood ratio test with 0.05 as significance level. Net survival and excess mortality rate curves were drawn for each combination of cancer site, sex, and age group.

\section{Estimation of net survival with assumption of cure}

The net survival was estimated using the flexible parametric net survival cure model developed by Andersson et al. $[16,17]$. This model derives from the net survival model without assumption of cure [14]. The assumption of cure adds the constraint that the $\log$ cumulative excess hazard has to be constant (slope $=0$ ) beyond the last boundary knot. The modelling strategy was identical to that without assumption of cure, except an additional internal knot located at the $99^{\text {th }}$ percentile. The latter additional knot allowed an optimal estimation of net survival with the cure model. 


\section{Assumption of statistical cure}

The assumption of statistical cure was assessed graphically by site, sex, and age group using the excess mortality rate modelled without assumption of cure. The estimated excess mortality rate was considered negligible in case of sustained value $\leq 0.05$ and the net survival was modelled with assumption of cure. The adequacy of the estimates of net survival using flexible models with and without assumption of cure was evaluated by checking whether the curves overlap. In case of satisfactory adequacy, cure was considered acceptable and the cure proportion and time-to-cure were estimated.

\section{Indicators of cure from cancer}

Two cure indicators were estimated only for combinations of site, sex, and age for which the assumption of cure was accepted:

- The cure proportion (P) commonly provided in statistical cure studies $[2-4,10]$ is the proportion of patients who will never die from the cancer under study. Its value ranges from 0 to 1.

- The time-to-cure was recently defined as TTC by Boussari et al. [5] using $\mathrm{P}(\mathrm{t})$, the individual probability for a patient with given characteristics (sex and age at diagnosis) of belonging to the cured group knowing that he/she is still alive at time $\mathrm{t}$ [11]:

$$
P(t)=\frac{P}{S_{n}(t)}
$$

with $S_{n}(t)$ : the net survival estimated at $t$

Cure models assume that a given patient belongs to a given group (cured or uncured) since diagnosis. For $\mathrm{t}=0, \mathrm{~S}_{\mathrm{n}}(\mathrm{t})=1$ thus $\mathrm{P}(\mathrm{t})=\mathrm{P}$. For $\mathrm{t} \rightarrow+\infty, \mathrm{S}_{\mathrm{n}}(\mathrm{t}) \rightarrow \mathrm{P}$; thus $\mathrm{P}(\mathrm{t}) \rightarrow 1$. In other words, the probability $\mathrm{P}(\mathrm{t})$ that this patient belongs to the cured group is $\mathrm{P}$ at the time of diagnosis and increases as time goes by and the patient is still alive. We defined the TTC as TTC_95: i.e., the time $\mathrm{t}$ after diagnosis after which $\mathrm{P}(\mathrm{t})$ exceeds 95\% [5]. The confidence intervals relative to P and TTC were calculated by the Delta method. 
stpm2 command in STATA ${ }^{\mathrm{TM}}$, release 14 (STATA corp., College Station, Texas) was used to fit flexible parametric net survival models with and without cure option $[17,18]$.

\section{Results}

Overall, 335358 solid tumours from 22 cancer sites in men and 21 in women were included. The most frequent were breast (49\% of women cancers), prostate ( $28 \%$ of men cancers), lung (16\% in men and 5\% in women) and colorectal cancer (15\% in men and $13 \%$ in women).

The assumption of statistical cure for each cancer site, sex, and age-group combination was checked using the excess mortality rate and the net survival curves. The graphs used to check the assumption of statistical cure are presented in Appendix A and the results of the checks in Table 1 for men and Table 2 for women. The assumption of cure was rejected for: cancers of the oesophagus and the oral cavity in both sexes; larynx, lung, and tongue cancers in both sexes and age group 55-74; hypopharynx, pleural mesothelioma, and oropharynx cancers in men; bone, liver, and small intestine cancers in men aged 65-74; head and neck cancers in all men and in women aged 45-74; and central nervous system cancers in men aged 15-44 and men and women aged 55-74.

In cases with accepted assumption of cure, Tables 3 and 4 show, respectively, in men and women, P and TTC values (with their 95\% CIs) and the lower left quadrant of Appendix A provides $\mathrm{P}(\mathrm{t})$. These results are described below according to three ranges of TTC: $<5$ years, 5 to 10 years, and >10 years. In Figures 1 to 3, adapted from Verdecchia et al.[10], $\mathrm{P}$ is plotted against TTC to show changes of P and TTC values with sex and age and allow visual comparisons between cancer sites.

\section{Time-to-cure $<5$ years (Figure 1)}

Thyroid and testis cancers and skin melanoma had the shortest TTC. Cure was considered reached right after diagnosis $(\mathrm{P}>95 \%$ thus $\mathrm{TTC}=0)$ in thyroid cancer in men and women 
aged 15-44 and in women aged $<65$ (Figure 1.a) and in testis cancer in men aged $<55$ (Figure 1.b). TTC was $<2$ years and $\mathrm{P}$ was $>80 \%$ in men aged $45-54$ with thyroid cancer and men aged $\geq 55$ with testis cancer. Cure from skin melanoma was reached within 5 years (Figure 1.c) in all patients aged $<55$ and in men aged 55-64; $\mathrm{P}$ was around $90 \%$ in women and $85 \%$ in men. Though $\mathrm{P}$ was $>60 \%$, cure was reached after 6 to 10 years in all patients aged 65-74 and men aged 55-64 with thyroid cancer and in all patients aged 65-74 and women aged 55-64 with skin melanoma.

\section{Time-to-cure 5 to 10 years (Figure 2)}

In all digestive cancers (except small intestine) and all gynaecologic cancers (except breast), cure was reached within 5 to 10 years.

Among digestive cancers, $\mathrm{P}$ was the highest in colorectal cancer (Figure 2.a). P was slightly higher in women vs. men and decreased with age from 62 to $55 \%$ in women and from 59 to $48 \%$ in men. The TTC increased with age and cure was reached earlier in women vs. men. The TTC ranged from 6.8 to 9.2 years in women and from 9.3 to 10.8 years in men. $\mathrm{P}$ was the lowest in pancreas cancer (Figure 2.c). Under 45 years, $\mathrm{P}$ was $10 \%$ in men and $16 \%$ in women and about $5 \%$ in older patients. The TTC ranged from 8 to 9 years and did not change with sex or age. For stomach cancer (Figure 2.b), P decreased with age from 30 to $19 \%$ in men and from 30 to $25 \%$ in women. The TTC ranged from 9 to 10 years whatever the sex and age.

Among gynaecologic cancers, $\mathrm{P}$ was overall higher for corpus uteri than for cervix uteri or ovary (Figure 2.d). It decreased with increasing age from 81 to $63 \%$. The corresponding figures for cervix uteri were $77 \%$ and $46 \%$ (Figure 2.e). For corpus and cervix uteri, the TTC was similar and increased with age from 7 to 11 years. For ovary, P decreased with increasing age from 62 to $22 \%$ (Figure 2.f). Cure was reached at 8.4 years in the youngest and 11 years in the oldest. 


\section{Time-to-cure $>10$ years (Figure 3)}

Cure was reached past 10 years in urinary tract (kidney and bladder), breast and prostate cancers. For prostate and breast cancers (Figures 3.a \& 3.b), TTC ranged between 10 and 12 years though $\mathrm{P}$ was very high. $\mathrm{P}$ varied with age between 80 and $88 \%$ for prostate cancer and between 72 and $80 \%$ for breast cancer.

$\mathrm{P}$ was higher for kidney than for bladder cancer (Figures 3.c \& 3.d). For kidney, $\mathrm{P}$ decreased with increasing age from 74 to $49 \%$ in men and from 79 to $54 \%$ in women. For bladder, P ranged from 56 to $37 \%$ in men and from 46 to $40 \%$ in women. For kidney cancers diagnosed after age 45, the TTC ranged from 12 to 13 years in men and from 10 to 12 years in women. For bladder, cure was reached within 12 to13 years whatever the sex and age.

\section{Discussion}

Among the 335,358 cancer cases registered 1989 to 2009 in patients aged 15 to 74 years, the TTC was $<12$ years for most cancer sites.

With cure proportions $>95 \%$, cure occurred right after diagnosis in men aged $<55$ with testis cancer and in men $<45$ and women $<65$ with thyroid cancer. For skin melanoma, testis cancers and thyroid cancers diagnosed before age 65 , the cure proportions were $>80 \%$ and cure was reached within 5 years. For breast and prostate cancers (the most frequent in France), cure occurred after 10 years despite very high cure proportions (72 to $88 \%$ ). For colorectal cancer, cure was reached between 5 and 10 years.

Previous studies have reported net survival advantages in women vs. men [19]. Here, we show higher cure proportions in women than in men in nearly all cancer sites, except tissue sarcoma, biliary tract, and bladder cancers. Regarding TTC, sex disparity was not uniform; e.g., the TTC was shorter in women regarding colorectal or kidney cancer but longer regarding skin melanoma or tissue sarcoma. In both sexes and most cancer sites, the TTC increased and the cure proportion decreased with increasing age at diagnosis. Plotting 
TTC vs. P depicts the proportion of patients to whom the TTC applies. For instance, when P is very low (melanoma or cancer of the lung or the pancreas), the TTC has less importance than when $\mathrm{P}$ is very high.

Regarding age disparities, the rejection of the cure assumption in the older age groups in several cancer sites was in agreement with net survival studies on the same French registry data [13] (absence of plateau in the corresponding sites/age groups).

To be excluded, a cancer site had to meet both conditions of $<500$ incident cases and $<200$ deaths. This allowed keeping in the analysis cancers with good prognosis and reasonable numbers of incident cases. Among the cancer sites excluded because the number of cases was $<500$ and the number of deaths was $<200$, only penile cancer had a low excess mortality rate. However, in France, penile cancer is rare: its crude incidence rate is 1.14 per 100,000 person-years [20].

This study is the first to provide cure proportions and TTC for cancers in France. Its strengths are: i) the exhaustiveness of the study due to a population-based recruitment; ii) the use of flexible parametric cure models that have shown advantages over other approaches [21]; iii) almost exact overlap of model-estimated net survivals with and without cure when the assumption of cure was accepted; and iv) the use of a recent definition of TTC [5]. Indeed, for the first time, the TTC was estimated from the individual probability of being cured [5]. This intuitive definition of TTC indicates the time after which patients can be reasonably confident in belonging to the cured group. From this time, the observed mortality rate equals the mortality of the general population. Although statistically cured patients would not die from cancer, they are still subject to death from other causes with the same probability as the general population.

Only two previous studies have estimated the time-to-cure from the net survival of the uncured [22] and from the 10-year conditional net survival (survival for additional 10 years) [4], but with limitations [5]: the former can be over-influenced by the early excess mortality because it depends only on the survival of the uncured. For a given long-term 
excess mortality, a high early excess mortality brings the estimate of this time-to-cure closer to the date of diagnosis than a lower early excess mortality. The latter assumes a monotonously increasing function for the conditional net survival and requires long-term follow-ups. Only one study has been published with estimations of the time-to-cure [4] using the conditional net survival. Our results are similar to those obtained by Dal Maso et al. [4], particularly regarding sex-related and age-related differences.. However, there are two discrepancies i) when $\mathrm{P}>95 \%$, TTC values here are 0 vs. 1-2 year in men $<55$ years with testicular cancer and 1-4 years in women $<65$ years with thyroid cancer in the Italian study; ii) TTC of 10 years here vs. 5 years in women aged $65-75$ with thyroid cancer in the Italian study (probably because of lack of monotony: in our data, the 10-year conditional net survival decreased between 5 and 8 years then increased to reach $95 \%$ only 10 years after diagnosis). The similarity of the results between our study and the Italian study are in agreement with the 5-year survivals found in EUROCARE studies [23]. Applied to other countries with different health policies (e.g., cancer prevention or screening) or with different risk factors due to different lifestyles, this method might show different TTCs for same cancer sites.

One limitation of the present study is the lack of information on well-recognised prognostic factors such as cancer stage. The main limitation of all cure models is the absence of implemented statistical tests. This imposes a graphical checking of the assumption of cure that requires criteria. Our criteria (excess mortality $\leq 0.05$ and adequacy of net survival curves) may be questioned: different criteria would have led to different selections of cancer site, sex, and age combinations; furthermore, the threshold used to define TTC was arbitrarily chosen. Moreover, the post estimation of the TTC might have yielded very wide confidence intervals in case of low cancer incidence or lethal cancer. We are currently developing a cure model that includes time-to-cure (defined as the time at which the excess mortality rate becomes null) as a parameter to estimate. This approach will allow testing the assumption of cure and will provide a more accurate estimation of the time 
at which cure is reached because it will not use an approximation based on a predefined threshold.

Although statistical cure is not directly related to clinical cure, the cure proportion and the TTC are important indicators for policy making, medical practice, and patient information. In France, cancer patients cannot access to credit or have to pay high extra insurance premiums; however, since 2015 , cancer declaration is no more mandatory $\geq 10$ years after the end of cancer treatment (also called: "right to be forgotten") [24]. The present results suggest that the durations of extra premiums should be shortened, not only after testis cancer, thyroid cancer, and skin melanoma where statistical cure occurs shortly after diagnosis, but and also after other cancers whose cure is reached $\leq 10$ years after diagnosis. 


\section{Acknowledgements}

The authors wish to thank the French network of cancer registries (FRANCIM) for providing the study data. They also thank Stéphanie Normand (Registre Bourguignon des Cancers Digestifs, France) for her technical assistance.

\section{Funding}

This work was supported by the Institut National du Cancer [grant INCa 2014-087].

\section{Declarations of interest: none}

\section{French Network of Cancer Registries (FRANCIM):}

Brice Amadeo (Registre des cancers de Gironde), Patrick Arveux (Registre des cancers du sein et des cancers gynécologiques de Côte-d'Or), Isabelle Baldi (Registre des tumeurs primitives du système nerveux de la Gironde), Simona Bara (Registre des cancers de la Manche), Anne- Marie Bouvier (Registre bourguignon des cancers digestifs), Véronique Bouvier (Registre des tumeurs digestives du Calvados), Jacqueline Clavel (Registre des hémopathies malignes de l'enfant), Marc Colonna (Registre du cancer de l'Isère), Gaëlle Coureau (Registre des cancers de Gironde), Anne Cowppli-Bony (Registre des tumeurs de Loire-Atlantique et Vendée), Tania Dalmeida (Registre général des cancers de Haute Vienne), Laetitia Daubisse-Marliac (Registre des cancers du Tarn), Gautier Defossez (Registre général des cancers de Poitou-Charentes), Patricia Delafosse (Registre du cancer de l'Isère), Jacqueline Deloumeaux (Registre général des cancers de Guadeloupe), Pascale Grosclaude (Registre des cancers du Tarn), Anne-Valérie Guizard (Registre général des tumeurs du Calvados), Clarisse Joachim (Registre général des cancers de Martinique), Brigitte Lacour (Registre National des Tumeurs Solides de l'Enfant), Bénédicte LapôtreLedoux (Registre du cancer de la Somme), Emilie Marrer (Registre des cancers du HautRhin), Marc Maynadié (Registre des hémopathies malignes de Côte d'Or), Florence Molinié 
(Registre des tumeurs de Loire-Atlantique et Vendée), Alain Monnereau (Registre des hémopathies malignes de la Gironde), Jean-Baptiste Nousbaum (Registre finistérien des tumeurs digestives), Juliette Plenet (Registre des Cancers de Guyane), Sandrine Plouvier (Registre général des cancers de Lille et de sa région),Camille Pouchieu (Registre des tumeurs primitives du système nerveux de la Gironde), Michel Robaszkiewicz (Registre finistérien des tumeurs digestives), Claire Schvartz (Registre des cancers thyroïdiens MarneArdennes), Brigitte Trétarre (Registre des tumeurs de l'Hérault), Xavier Troussard (Registre Régional des Hémopathies Malignes de Basse Normandie), Michel Velten (Registre des cancers du Bas-Rhin), Anne-Sophie Woronoff (Registre des tumeurs du Doubs et du Territoire de Belfort). 


\section{References}

[1] M. Colonna, N. Mitton, N. Bossard, A. Belot, P. Grosclaude, Total and partial cancer prevalence in the adult French population in 2008, BMC cancer 15 (2015) 153.

[2] S. Francisci, R. Capocaccia, E. Grande, M. Santaquilani, A. Simonetti, C. Allemani, G. Gatta, M. Sant, G. Zigon, F. Bray, M. Janssen-Heijnen, The cure of cancer: a European perspective, European journal of cancer (Oxford, England : 1990) 45(6) (2009) 1067-79.

[3] M. Cvancarova, B. Aagnes, S.D. Fossa, P.C. Lambert, B. Moller, F. Bray, Proportion cured models applied to 23 cancer sites in Norway, International journal of cancer 132(7) (2013) 1700-10.

[4] L. Dal Maso, S. Guzzinati, C. Buzzoni, R. Capocaccia, D. Serraino, A. Caldarella, A.P. Dei Tos, F. Falcini, M. Autelitano, G. Masanotti, S. Ferretti, F. Tisano, U. Tirelli, E. Crocetti, R. De Angelis, Long-term survival, prevalence, and cure of cancer: a populationbased estimation for 818902 Italian patients and 26 cancer types, Annals of oncology : official journal of the European Society for Medical Oncology 25(11) (2014) 2251-60.

[5] O. Boussari, G. Romain, L. Remontet, N. Bossard, M. Mounier, A.M. Bouvier, C. Binquet, M. Colonna, V. Jooste, A new approach to estimate time-to-cure from cancer registries data, Cancer epidemiology 53 (2018) 72-80.

[6] P.W. Dickman, A. Sloggett, M. Hills, T. Hakulinen, Regression models for relative survival, Statistics in medicine 23(1) (2004) 51-64.

[7] K.A. Cronin, E.J. Feuer, Cumulative cause-specific mortality for cancer patients in the presence of other causes: a crude analogue of relative survival, Statistics in medicine 19(13) (2000) 1729-1740.

[8] J. Esteve, E. Benhamou, M. Croasdale, L. Raymond, Relative survival and the estimation of net survival: elements for further discussion, Statistics in medicine 9(5) (1990) 529-38.

[9] T. Hakulinen, L. Tenkanen, Regression analysis of relative survival rates, Appl Stat 36 (1987) 309-17.

[10] A. Verdecchia, R. De Angelis, R. Capocaccia, M. Sant, A. Micheli, G. Gatta, F. Berrino, The cure for colon cancer: results from the EUROCARE study, International journal of cancer 77(3) (1998) 322-9.

[11] R. Sposto, Cure model analysis in cancer: an application to data from the Children's Cancer Group, Statistics in medicine 21(2) (2002) 293-312.

[12] A. Fritz, C. Percy, A. Jack, International classification of diseases for oncology.3rd ed. Geneva: World Health Organization, (2000).

[13] A. Cowppli-Bony, Z. Uhry, L. Remontet, N. Voirin, A.V. Guizard, B. Tretarre, A.M. Bouvier, M. Colonna, N. Bossard, A.S. Woronoff, P. Grosclaude, Survival of solid cancer patients in France, 1989-2013: a population-based study, European journal of cancer prevention : the official journal of the European Cancer Prevention Organisation (ECP) 26(6) (2017) 461-468.

[14] P. Lambert, P. Royston, Further development of flexible parametric models for survival analysis., The Stata Journal 9 (2009) 265-290.

[15] C.P. Nelson, P.C. Lambert, I.B. Squire, D.R. Jones, Flexible parametric models for relative survival, with application in coronary heart disease, Statistics in medicine 26(30) (2007) 5486-98.

[16] T.M. Andersson, P.W. Dickman, S. Eloranta, P.C. Lambert, Estimating and modelling cure in population-based cancer studies within the framework of flexible parametric survival models, BMC medical research methodology 11 (2011) 96.

[17] T.M.L. Andersson, P.C. Lambert, Fitting and modeling cure in population-based cancer studies within the framework of flexible parametric survival models., The Stata Journal 12 (2012) 623-628.

[18] P.C. Lambert, P. Royston, Further development of flexible parametric models for survival analysis, Stata Journal 9(2) (2009) 265-290. 
[19] M.L. Janssen-Heijnen, A. Gondos, F. Bray, T. Hakulinen, D.H. Brewster, H. Brenner, J.W. Coebergh, Clinical relevance of conditional survival of cancer patients in europe: agespecific analyses of 13 cancers, Journal of clinical oncology : official journal of the American Society of Clinical Oncology 28(15) (2010) 2520-8.

[20] L. Daubisse-Marliac, M. Colonna, B. Tretarre, G. Defossez, F. Molinie, K. JehanninLigier, E. Marrer, P. Grosclaude, Long-term trends in incidence and survival of penile cancer in France, Cancer epidemiology 50(Pt A) (2017) 125-131.

[21] X.Q. Yu, R. De Angelis, T.M. Andersson, P.C. Lambert, D.L. O'Connell, P.W. Dickman, Estimating the proportion cured of cancer: some practical advice for users, Cancer epidemiology 37(6) (2013) 836-42.

[22] M. Chauvenet, C. Lepage, V. Jooste, V. Cottet, J. Faivre, A.M. Bouvier, Prevalence of patients with colorectal cancer requiring follow-up or active treatment, European journal of cancer (Oxford, England : 1990) 45(8) (2009) 1460-5.

[23] R. De Angelis, M. Sant, M.P. Coleman, S. Francisci, P. Baili, D. Pierannunzio, A. Trama, O. Visser, H. Brenner, E. Ardanaz, M. Bielska-Lasota, G. Engholm, A. Nennecke, S. Siesling, F. Berrino, R. Capocaccia, Cancer survival in Europe 1999-2007 by country and age: results of EUROCARE--5-a population-based study, The Lancet. Oncology 15(1) (2014) 23-34.

[24] F. Binder-Foucard, N. Bossard, P. Delafosse, A. Belot, A.S. Woronoff, L. Remontet, Cancer incidence and mortality in France over the 1980-2012 period: solid tumors, Revue d'epidemiologie et de sante publique 62(2) (2014) 95-108. 


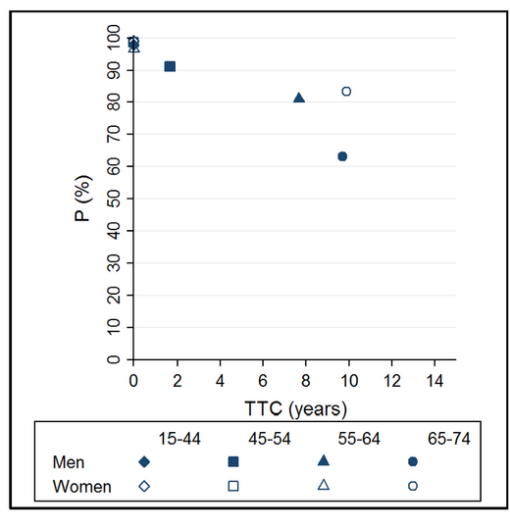

a. Thyroid cancer

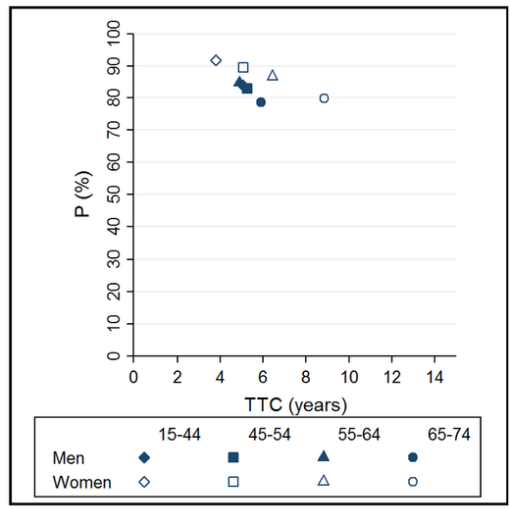

c. Skin melanoma

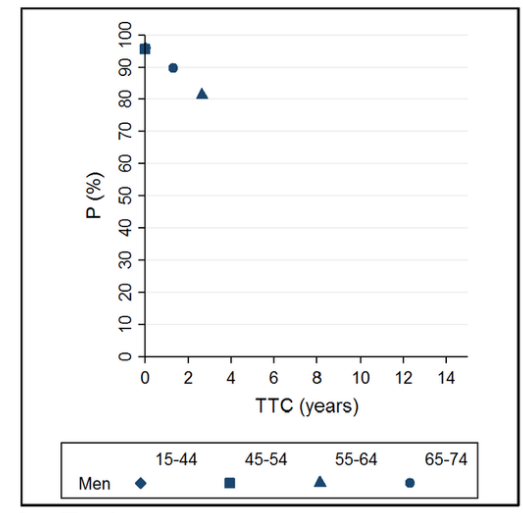

b. Testis cancer

Figure 1. Cure proportion (P) and time-to-cure (TTC) in cancer sites with $\mathrm{TTC} \leq 5$ years for some combinations of sex and age at diagnosis. 


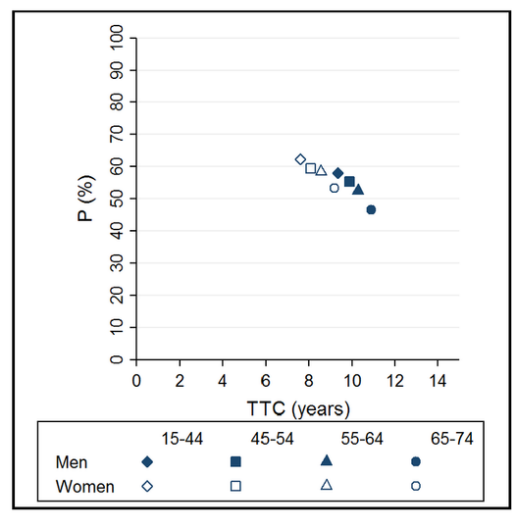

a. Colorectal cancer

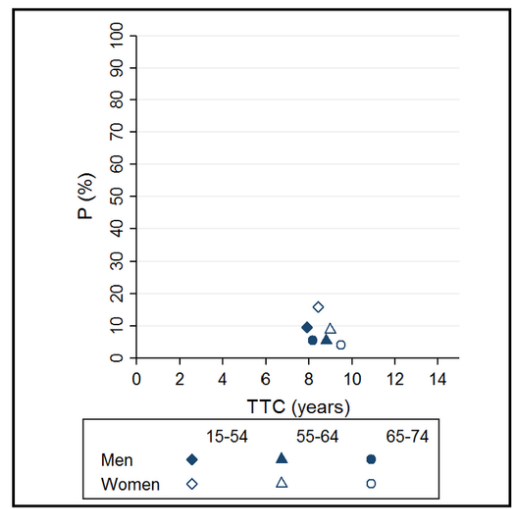

c. Pancreatic cancer

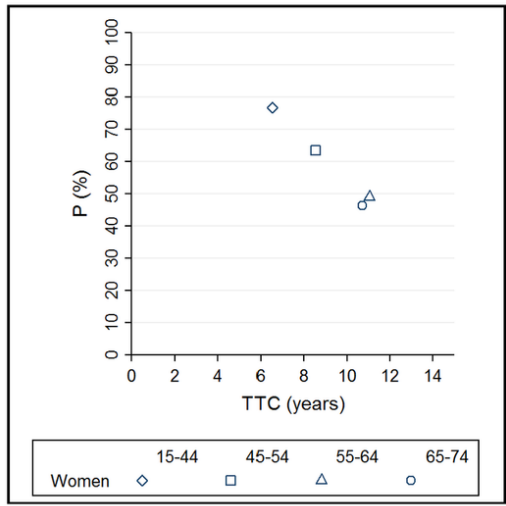

e. Cervix uteri cancer

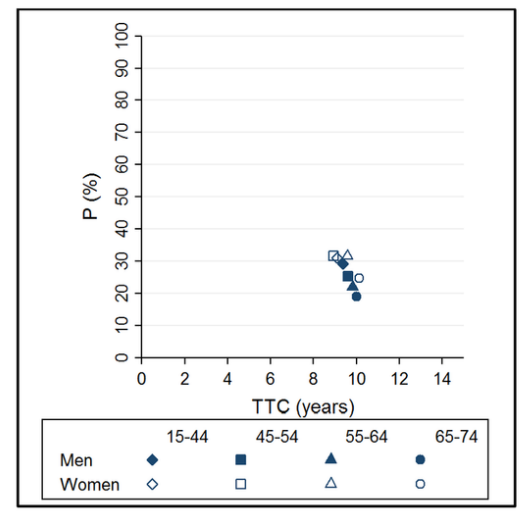

b. Stomach cancer

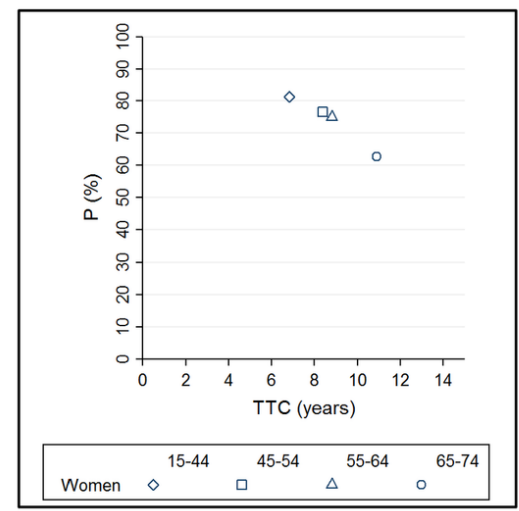

d. Corpus uteri cancer

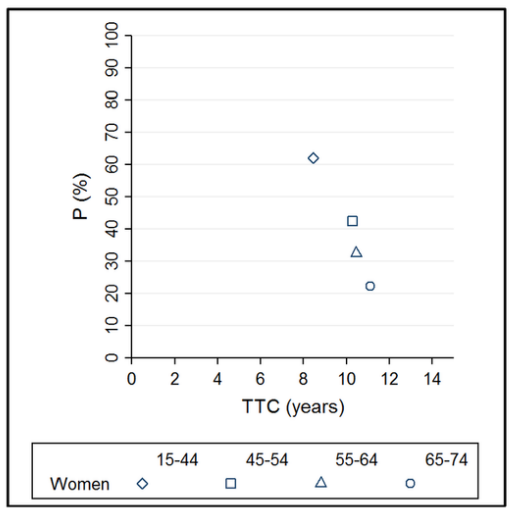

f. Ovary cancer

Figure 2. Cure proportion (P) and time-to-cure (TTC). Examples of cancer sites with TTC between 5 and 10 years for some combinations of sex and age at diagnosis. 


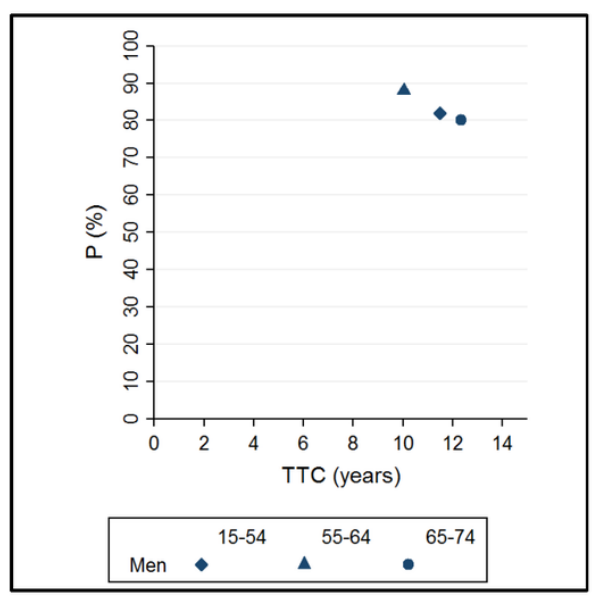

a. Prostate cancer

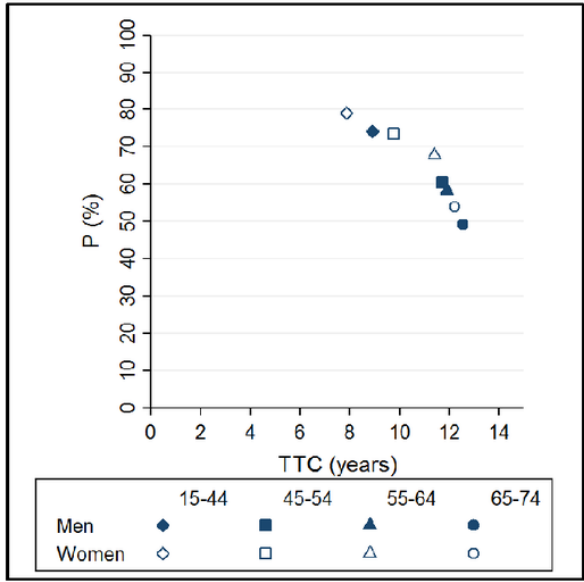

c. Kidney cancer

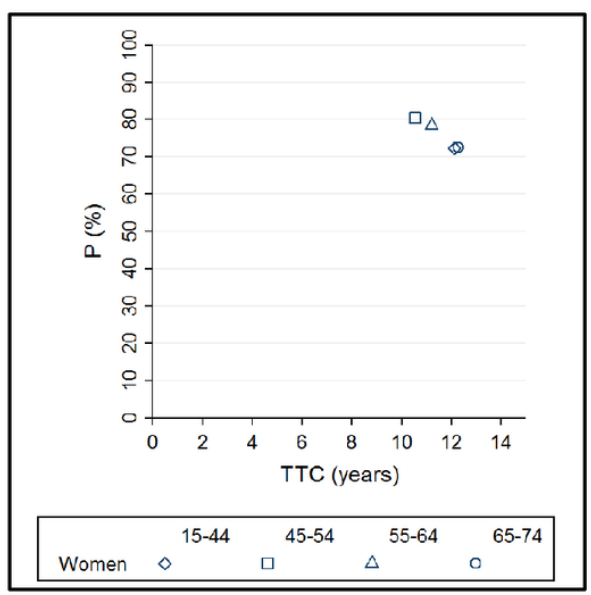

b. Breast cancer

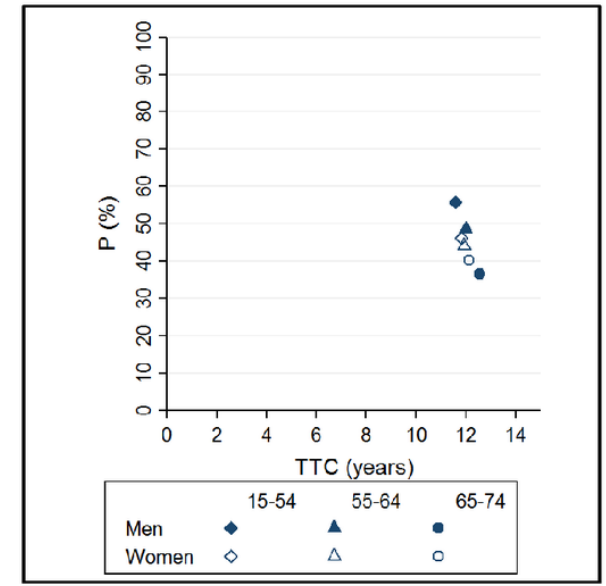

d. Bladder cancer

Figure 3. Cure proportion (P) and time-to-cure (TTC). Examples of cancer sites with TTC $>10$ years for most combinations of sex and age at diagnosis. 


\begin{tabular}{|c|c|c|c|c|c|c|c|c|c|}
\hline Cancer site & $\begin{array}{l}\text { Number at } \\
\text { diagnosis }\end{array}$ & $\begin{array}{l}\text { Number at } 5 \\
\text { years }\end{array}$ & $\begin{array}{l}\text { Number at } \\
10 \text { years }\end{array}$ & $\begin{array}{l}\text { Number } \\
\text { deaths }^{\mathrm{a}}\end{array}$ & $\begin{array}{l}\text { Percentage of } \\
\text { loss to follow-up }\end{array}$ & $15-44$ years & $45-54$ years & $55-64$ years & $65-74$ years \\
\hline Bones & 405 & 236 & 199 & 219 & 3.2 & $\mathrm{C}$ & $\mathrm{C}$ & $\mathrm{C}$ & $\mathrm{NC}$ \\
\hline Central nervous system & 2925 & 614 & 479 & 2475 & 1.1 & $\mathrm{NC}$ & $\mathrm{C}$ & $\mathrm{NC}$ & $\mathrm{NC}$ \\
\hline Choroid $^{\mathrm{b}}$ & 281 & 194 & 161 & 123 & 1.1 & - & - & - & - \\
\hline Colon $^{\mathrm{c}}$ & 16029 & 9206 & 7769 & 8803 & 2.1 & $\mathrm{C}$ & $\mathrm{C}$ & $\mathrm{C}$ & $\mathrm{C}$ \\
\hline Colon and Rectum & 27861 & 15959 & 13279 & 15538 & 2.0 & $\mathrm{C}$ & $\mathrm{C}$ & $\mathrm{C}$ & $\mathrm{C}$ \\
\hline Head and neck & 14137 & 4829 & 3317 & 11297 & 1.0 & $\mathrm{NC}$ & $\mathrm{NC}$ & $\mathrm{NC}$ & $\mathrm{NC}$ \\
\hline Kidney & 6183 & 4149 & 3580 & 2840 & 2.0 & $\mathrm{C}$ & $\mathrm{C}$ & $\mathrm{C}$ & $\mathrm{C}$ \\
\hline $\operatorname{Lip}^{b}$ & 400 & 327 & 276 & 167 & 4.5 & - & - & - & - \\
\hline Lung & 30072 & 4620 & 3371 & 27052 & 0.8 & $\mathrm{C}$ & $\mathrm{C}$ & $\mathrm{NC}$ & $\mathrm{NC}$ \\
\hline $\begin{array}{l}\text { Malignant neoplasm without } \\
\text { specification of site }^{b}\end{array}$ & 132 & 33 & 30 & 103 & 4.3 & - & - & - & - \\
\hline Nasopharynx ${ }^{\mathrm{c}}$ & 339 & 177 & 141 & 206 & 3.5 & $\mathrm{C}$ & $\mathrm{C}$ & $\mathrm{C}$ & $\mathrm{NC}$ \\
\hline Oral cavity $^{c}$ & 3211 & 1305 & 908 & 2430 & 1.2 & $\mathrm{NC}$ & $\mathrm{NC}$ & $\mathrm{NC}$ & $\mathrm{NC}$ \\
\hline $\operatorname{Rectum}^{\mathrm{c}}$ & 11832 & 6753 & 5510 & 6735 & 1.9 & $\mathrm{C}$ & $\mathrm{C}$ & $\mathrm{C}$ & $\mathrm{C}$ \\
\hline Skin melanoma & 4571 & 3804 & 3508 & 1158 & 4.3 & $\mathrm{C}$ & $\mathrm{C}$ & $\mathrm{C}$ & $\mathrm{C}$ \\
\hline Stomach & 5460 & 1415 & 1153 & 4397 & 1.8 & $\mathrm{C}$ & $\mathrm{C}$ & $\mathrm{C}$ & $\mathrm{C}$ \\
\hline Testis & 3021 & 2864 & 2826 & 226 & 3.7 & $\mathrm{C}$ & $\mathrm{C}$ & $\mathrm{C}$ & $\mathrm{C}$ \\
\hline Thyroid & 2060 & 1808 & 1708 & 381 & 2.6 & $\mathrm{C}$ & $\mathrm{C}$ & $\mathrm{C}$ & $\mathrm{C}$ \\
\hline Tissue sarcoma & 1168 & 669 & 593 & 607 & 2.0 & $\mathrm{C}$ & $\mathrm{C}$ & $\mathrm{C}$ & $\mathrm{C}$ \\
\hline \multirow[t]{2}{*}{ Tongue $^{c}$} & 2624 & 913 & 658 & 2051 & 1.2 & $\mathrm{C}$ & $\mathrm{NC}$ & $\mathrm{NC}$ & $\mathrm{NC}$ \\
\hline & & & & & & 15-54 years & & 55-64 years & $65-74$ years \\
\hline Biliary tract & 1095 & 235 & 184 & 930 & 0.8 & $\mathrm{C}$ & & $\mathrm{C}$ & $\mathrm{C}$ \\
\hline Bladder & 7972 & 4343 & 3500 & 4823 & 2.1 & $\mathrm{C}$ & & $\mathrm{C}$ & $\mathrm{C}$ \\
\hline Hypopharynx ${ }^{c}$ & 3531 & 960 & 597 & 3038 & 0.7 & $\mathrm{NC}$ & & $\mathrm{NC}$ & $\mathrm{NC}$ \\
\hline Larynx & 4347 & 2330 & 1800 & 2768 & 1.9 & $\mathrm{C}$ & & $\mathrm{NC}$ & $\mathrm{NC}$ \\
\hline Liver & 7165 & 1039 & 703 & 6498 & 0.9 & $\mathrm{C}$ & & $\mathrm{NC}$ & $\mathrm{NC}$ \\
\hline Nasal cavity & 562 & 284 & 220 & 360 & 1.4 & $\mathrm{C}$ & & $\mathrm{C}$ & $\mathrm{C}$ \\
\hline Oropharynx $^{c}$ & 3776 & 1322 & 913 & 2998 & 0.8 & $\mathrm{NC}$ & & $\mathrm{NC}$ & $\mathrm{NC}$ \\
\hline Oesophagus & 6047 & 839 & 530 & 5580 & 0.6 & $\mathrm{NC}$ & & $\mathrm{NC}$ & $\mathrm{NC}$ \\
\hline Pancreas & 4930 & 418 & 345 & 4607 & 1.1 & $\mathrm{C}$ & & $\mathrm{C}$ & $\mathrm{C}$ \\
\hline Penis ${ }^{b}$ & 336 & 231 & 207 & 146 & 1.8 & - & & - & - \\
\hline Pleural mesothelioma & 592 & 32 & 15 & 579 & 0.7 & $\mathrm{NC}$ & & $\mathrm{NC}$ & $\mathrm{NC}$ \\
\hline Prostate & 52279 & 44567 & 39590 & 14736 & 2.8 & $\mathrm{C}$ & & $\mathrm{C}$ & $\mathrm{C}$ \\
\hline Salivary glands ${ }^{\mathrm{b}}$ & 368 & 220 & 190 & 192 & 2.2 & - & & - & - \\
\hline Small intestine & 710 & 359 & 296 & 435 & 1.7 & $\mathrm{C}$ & & $\mathrm{C}$ & $\mathrm{NC}$ \\
\hline Urinary tract & 722 & 324 & 268 & 472 & 1.9 & $\mathrm{C}$ & & $\mathrm{C}$ & $\mathrm{C}$ \\
\hline
\end{tabular}

C: cure; NC: no cure; ${ }^{\text {a }}$ At 15 years or on June 30,$2013 ;{ }^{b}$ Not analysed because $<500$ cases at diagnosis and <200 deaths; ${ }^{\mathrm{c}}$ Cancer sub-sites

Table 1. Results of checking the assumption of cure by age-group at diagnosis in men. 


\begin{tabular}{|c|c|c|c|c|c|c|c|c|c|}
\hline Cancer site & $\begin{array}{l}\text { Number at } \\
\text { diagnosis }\end{array}$ & $\begin{array}{l}\text { Number at } 5 \\
\text { years }\end{array}$ & $\begin{array}{l}\text { Number at } \\
10 \text { years }\end{array}$ & $\begin{array}{l}\text { Number } \\
\text { deaths }^{\text {a }}\end{array}$ & $\begin{array}{l}\text { Percentage of } \\
\text { loss to follow-up }\end{array}$ & $15-44$ years & $45-54$ years & 55-64 years & $65-74$ years \\
\hline Bones ${ }^{b}$ & 323 & 214 & 197 & 131 & 3.1 & - & - & - & - \\
\hline Breast & 71947 & 63289 & 58145 & 16125 & 3.4 & $\mathrm{C}$ & $\mathrm{C}$ & $\mathrm{C}$ & $\mathrm{C}$ \\
\hline Central nervous system & 2148 & 510 & 435 & 1745 & 1.9 & $\mathrm{C}$ & $\mathrm{C}$ & $\mathrm{NC}$ & $\mathrm{NC}$ \\
\hline Cervix uteri & 4407 & 3126 & 2918 & 1586 & 4.7 & $\mathrm{C}$ & $\mathrm{C}$ & $\mathrm{C}$ & $\mathrm{C}$ \\
\hline Choroid $^{\mathrm{b}}$ & 317 & 240 & 206 & 123 & 1.6 & - & - & - & - \\
\hline Colon $^{\mathrm{c}}$ & 11282 & 7129 & 6383 & 5182 & 3.8 & $\mathrm{C}$ & $\mathrm{C}$ & $\mathrm{C}$ & $\mathrm{C}$ \\
\hline Colon and Rectum & 18510 & 11749 & 10454 & 8536 & 3.7 & $\mathrm{C}$ & $\mathrm{C}$ & $\mathrm{C}$ & $\mathrm{C}$ \\
\hline Corpus uteri & 7315 & 5580 & 5118 & 2436 & 3.4 & $\mathrm{C}$ & $\mathrm{C}$ & $\mathrm{C}$ & $\mathrm{C}$ \\
\hline Head and neck & 2397 & 1213 & 968 & 1503 & 1.9 & $\mathrm{C}$ & $\mathrm{NC}$ & $\mathrm{NC}$ & $\mathrm{NC}$ \\
\hline Kidney & 2931 & 2188 & 1980 & 1051 & 3.8 & $\mathrm{C}$ & $\mathrm{C}$ & $\mathrm{C}$ & $\mathrm{C}$ \\
\hline Lip ${ }^{b}$ & 73 & 63 & 60 & 18 & 9.6 & - & - & - & - \\
\hline Lung & 6785 & 1492 & 1223 & 5647 & 1.5 & $\mathrm{C}$ & $\mathrm{C}$ & $\mathrm{NC}$ & $\mathrm{NC}$ \\
\hline $\begin{array}{l}\text { Malignant neoplasm without } \\
\text { specification of site } b\end{array}$ & 98 & 28 & 26 & 72 & 6.2 & - & - & - & - \\
\hline Nasopharynx & 109 & 67 & 61 & 51 & 4.6 & - & - & - & - \\
\hline Oral cavity $^{c}$ & 708 & 413 & 323 & 416 & 2.3 & $\mathrm{NC}$ & $\mathrm{NC}$ & $\mathrm{NC}$ & $\mathrm{NC}$ \\
\hline Ovary & 5753 & 2778 & 2256 & 3596 & 2.5 & $\mathrm{C}$ & $\mathrm{C}$ & $\mathrm{C}$ & $\mathrm{C}$ \\
\hline Rectum $^{c}$ & 7228 & 4620 & 4071 & 3354 & 3.5 & $\mathrm{C}$ & $\mathrm{C}$ & $\mathrm{C}$ & $\mathrm{C}$ \\
\hline Skin melanoma & 5466 & 5005 & 4794 & 783 & 6.2 & $\mathrm{C}$ & $\mathrm{C}$ & $\mathrm{C}$ & $\mathrm{C}$ \\
\hline Stomach & 2264 & 779 & 672 & 1627 & 4.0 & $\mathrm{C}$ & $\mathrm{C}$ & $\mathrm{C}$ & $\mathrm{C}$ \\
\hline Thyroid & 6702 & 6486 & 6342 & 448 & 4.2 & $\mathrm{C}$ & $\mathrm{C}$ & $\mathrm{C}$ & $\mathrm{C}$ \\
\hline Tissue sarcoma & 849 & 528 & 473 & 397 & 4.7 & $\mathrm{C}$ & $\mathrm{C}$ & $\mathrm{C}$ & $\mathrm{C}$ \\
\hline Tongue $^{c}$ & 605 & 310 & 262 & 360 & 2.8 & $\mathrm{C}$ & $\mathrm{NC}$ & $\mathrm{NC}$ & $\mathrm{NC}$ \\
\hline Vagina and Vulva & 683 & 411 & 358 & 344 & 4.5 & $\mathrm{C}$ & $\mathrm{C}$ & $\mathrm{C}$ & $\mathrm{C}$ \\
\hline & & & & & & \multicolumn{2}{|l|}{$15-54$ years } & 55-64 years & $65-74$ years \\
\hline Biliary tract & 1084 & 224 & 194 & 899 & 2.1 & \multicolumn{2}{|l|}{$\mathrm{C}$} & $\mathrm{C}$ & $\mathrm{C}$ \\
\hline Bladder & 1233 & 655 & 571 & 707 & 3.6 & \multicolumn{2}{|l|}{$\mathrm{C}$} & $\mathrm{C}$ & $\mathrm{C}$ \\
\hline Hypopharynx b,c & 242 & 85 & 53 & 196 & 2.5 & \multicolumn{2}{|l|}{-} & - & - \\
\hline Larynx & 419 & 250 & 217 & 224 & 2.4 & \multicolumn{2}{|l|}{$\mathrm{C}$} & $\mathrm{NC}$ & $\mathrm{NC}$ \\
\hline Liver & 1295 & 223 & 175 & 1125 & 1.8 & \multicolumn{2}{|l|}{$\mathrm{C}$} & $\mathrm{C}$ & $\mathrm{C}$ \\
\hline Nasal cavity & 165 & 82 & $69-$ & 99 & 4.2 & \multicolumn{2}{|l|}{-} & - & - \\
\hline Oropharynx & 665 & 317 & 252 & 427 & 2.6 & \multicolumn{2}{|l|}{$\mathrm{C}$} & $\mathrm{C}$ & $\mathrm{C}$ \\
\hline Oesophagus & 862 & 169 & 126 & 745 & 1.6 & \multicolumn{2}{|l|}{$\mathrm{NC}$} & $\mathrm{NC}$ & $\mathrm{NC}$ \\
\hline Pancreas & 3239 & 357 & 286 & 2967 & 0.9 & \multicolumn{2}{|l|}{$\mathrm{C}$} & $\mathrm{C}$ & $\mathrm{C}$ \\
\hline Pleural mesothelioma ${ }^{b}$ & 175 & 20 & 16 & 160 & 2.3 & \multicolumn{2}{|l|}{-} & - & - \\
\hline Salivary glands ${ }^{b}$ & 279 & 222 & 210 & 74 & 5.7 & \multicolumn{2}{|l|}{-} & - & - \\
\hline Small intestine & 527 & 305 & 255 & 283 & 4.2 & \multicolumn{2}{|l|}{$\mathrm{C}$} & $\mathrm{C}$ & $\mathrm{C}$ \\
\hline Urinary tract ${ }^{\mathrm{b}}$ & 254 & 111 & 90 & 169 & 2.0 & \multicolumn{2}{|l|}{-} & - & - \\
\hline
\end{tabular}

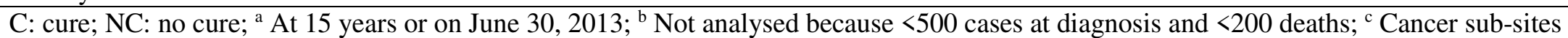

Table 2. Results of checking the assumption of cure by age-group at diagnosis in women. 


\begin{tabular}{|c|c|c|c|c|c|c|c|c|}
\hline \multirow{2}{*}{ Cancer site } & \multicolumn{2}{|c|}{$15-44$ years } & \multicolumn{2}{|c|}{$45-54$ years } & \multicolumn{2}{|c|}{$55-64$ years } & \multicolumn{2}{|c|}{$65-74$ years } \\
\hline & $\mathrm{P}(95 \% \mathrm{CI})$ & TTC (95\% CI) & $\mathrm{P}(95 \% \mathrm{CI})$ & TTC (95\% CI) & $\mathrm{P}(95 \% \mathrm{CI})$ & TTC (95\% CI) & $\mathrm{P}(95 \% \mathrm{CI})$ & TTC (95\% CI) \\
\hline Bones & $47(39-54)$ & $10.0(0.6-19.5)$ & $59(40-73)$ & $10.7(0.0-22.6)$ & $35(19-50)$ & $11.8(0.0-26.0)$ & $\mathrm{NC}$ & $\mathrm{NC}$ \\
\hline Central nervous system & $\mathrm{NC}$ & $\mathrm{NC}$ & $15(12-18)$ & $10.7(3.8-17.6)$ & $\mathrm{NC}$ & $\mathrm{NC}$ & $\mathrm{NC}$ & $\mathrm{NC}$ \\
\hline Colon ${ }^{\text {a }}$ & $59(55-64)$ & $9.2(4.3-14.1)$ & $58(55-60)$ & $9.4(6.6-12.3)$ & $55(53-57)$ & $10.0(8.1-11.9)$ & $48(46-50)$ & $10.8(9.3-12.3)$ \\
\hline Colon and Rectum & $58(55-61)$ & $9.3(5.9-12.8)$ & $55(53-57)$ & $9.9(8.0-11.7)$ & $53(51-54)$ & $10.3(9.0-11.6)$ & $47(45-48)$ & $10.9(9.7-12.0)$ \\
\hline Kidney & $74(69-79)$ & $8.9(3.0-14.8)$ & $61(57-64)$ & $11.7(9.4-14.0)$ & $58(55-62)$ & $11.9(9.9-13.9)$ & $49(45-53)$ & $12.5(10.5-14.6)$ \\
\hline Lung & $13(11-15)$ & $10.3(5.2-15.4)$ & $11(10-12)$ & $10.7(8.2-13.1)$ & $\mathrm{NC}$ & $\mathrm{NC}$ & $\mathrm{NC}$ & $\mathrm{NC}$ \\
\hline Nasopharynx ${ }^{a}$ & $55(41-67)$ & $11.0(2.1-19.9)$ & $41(29-53)$ & $11.8(2.7-20.8)$ & $32(21-43)$ & $12.2(2.2-22.2)$ & $\mathrm{NC}$ & $\mathrm{NC}$ \\
\hline Rectum $^{\text {a }}$ & $57(52-62)$ & $9.3(4.3-14.4)$ & $53(50-56)$ & $10.3(7.8-12.8)$ & $50(47-52)$ & $10.6(8.8-12.5)$ & $45(42-47)$ & $11.1(9.4-12.8)$ \\
\hline Skin melanoma & $84(81-86)$ & $5.1(3.9-6.2)$ & $83(79-86)$ & $5.2(3.8-6.6)$ & $85(81-88)$ & $4.9(3.5-6.2)$ & $79(75-82)$ & $5.9(4.2-7.6)$ \\
\hline Stomach & $29(24-34)$ & $9.4(2.2-16.5)$ & $25(22-28)$ & $9.6(4.8-14.4)$ & $22(20-24)$ & $9.8(6.0-13.6)$ & $19(17-21)$ & $10.0(6.7-13.3)$ \\
\hline Testis & $96(95-97)$ & 0 & $96(92-98)$ & 0 & $81(71-88)$ & $2.6(0.0-7.2)$ & $90(72-96)$ & $1.3(0.0-3.4)$ \\
\hline Thyroid & $98(95-99)$ & 0 & $91(87-94)$ & $1.7(0.1-3.3)$ & $81(74-86)$ & $7.7(4.7-10.6)$ & $63(53-72)$ & $9.7(5.3-14.1)$ \\
\hline Tissue sarcoma & $56(50-62)$ & $7.6(2.9-12.4)$ & $58(49-66)$ & $8.8(2.7-14.9)$ & $45(38-53)$ & $8.8(1.8-15.8)$ & $48(39-56)$ & $7.3(0.4-14.2)$ \\
\hline Tongue $^{\text {a }}$ & $37(30-44)$ & $11.8(6.5-17.1)$ & $\mathrm{NC}$ & $\mathrm{NC}$ & $\mathrm{NC}$ & $\mathrm{NC}$ & $\mathrm{NC}$ & $\mathrm{NC}$ \\
\hline \multicolumn{3}{|c|}{$15-54$ years } & & & \multicolumn{2}{|c|}{ 55-64 years } & \multicolumn{2}{|c|}{$65-74$ years } \\
\hline Biliary tracts & $22(16-30)$ & $9.1(0.0-22.4)$ & & & $15(11-21)$ & $10.5(0.1-20.9)$ & $16(13-20)$ & $9.8(1.0-18.6)$ \\
\hline Bladder & $56(52-59)$ & $11.6(9.3-13.9)$ & & & $49(46-51)$ & $12.0(10.3-13.7)$ & $37(34-39)$ & $12.6(11.0-14.2)$ \\
\hline Larynx & $37(34-40)$ & $13.1(11.1-15.1)$ & & & $\mathrm{NC}$ & $\mathrm{NC}$ & $\mathrm{NC}$ & $\mathrm{NC}$ \\
\hline Liver & $15(12-17)$ & $10.0(4.5-15.4)$ & & & $\mathrm{NC}$ & $\mathrm{NC}$ & $\mathrm{NC}$ & $\mathrm{NC}$ \\
\hline Nasal cavity & $42(33-51)$ & $12.0(6.5-17.4)$ & & & $33(24-41)$ & $12.4(6.1-18.7)$ & $33(25-41)$ & $12.3(6.2-18.5)$ \\
\hline Pancreas & $10(8-12)$ & $7.9(0.0-15.8)$ & & & $5(4-7)$ & $8.8(0.7-16.9)$ & $6(4-7)$ & $8.2(0.8-15.6)$ \\
\hline Prostate & $82(78-85)$ & $11.5(9.6-13.3)$ & & & $88(86-89)$ & $10.0(9.0-11.0)$ & $80(78-82)$ & $12.3(11.7-12.9)$ \\
\hline Small intestine & $50(40-58)$ & $11.3(5.0-17.6)$ & & & $42(33-51)$ & $11.6(4.9-18.3)$ & $\mathrm{NC}$ & $\mathrm{NC}$ \\
\hline Urinary tracts & $48(37-58)$ & $8.1(0.0-18.9)$ & & & $43(35-50)$ & $8.5(0.2-16.9)$ & $36(30-43)$ & $9.0(1.2-16.7)$ \\
\hline
\end{tabular}

NC : No Cure; ${ }^{a}$ Cancer subsite

Table 3. Estimated values of the cure proportion (P) and time-to-cure (TTC) in men by cancer site and age at diagnosis. 


\begin{tabular}{|c|c|c|c|c|c|c|c|c|}
\hline \multirow{2}{*}{ Cancer site } & \multicolumn{2}{|c|}{$15-44$ years } & \multicolumn{2}{|c|}{ 45-54 years } & \multicolumn{2}{|c|}{ 55-64 years } & \multicolumn{2}{|c|}{ 65-74 years } \\
\hline & $\mathrm{P}(95 \% \mathrm{CI})$ & TTC $(95 \%$ CI $)$ & $\mathrm{P}(95 \% \mathrm{CI})$ & TTC $(95 \%$ CI $)$ & $\mathrm{P}(95 \% \mathrm{CI})$ & TTC $(95 \%$ CI $)$ & $\mathrm{P}(95 \% \mathrm{CI})$ & TTC $(95 \%$ CI $)$ \\
\hline Breast & $72(71-74)$ & $12.1(11.5-12.7)$ & $80(80-81)$ & $10.6(10.0-11.1)$ & $79(78-79)$ & $11.2(10.6-11.8)$ & $73(71-74)$ & $12.3(11.7-12.9)$ \\
\hline Central nervous system & $38(33-42)$ & $10.4(6.2-14.5)$ & $19(15-23)$ & $10.8(3.3-18.3)$ & $\mathrm{NC}$ & $\mathrm{NC}$ & $\mathrm{NC}$ & $\mathrm{NC}$ \\
\hline Cervix uteri & $77(75-79)$ & $6.5(4.3-8.7)$ & $63(60-67)$ & $8.5(4.6-12.5)$ & $49(45-53)$ & $11.0(7.6-14.5)$ & $46(42-51)$ & $10.7(6.3-15.2)$ \\
\hline Colon $^{\mathrm{a}}$ & $62(58-66)$ & $7.4(3.8-11.1)$ & $62(59-64)$ & $6.8(4.5-9.2)$ & $58(56-60)$ & $8.1(6.1-10.1)$ & $55(53-57)$ & $8.6(6.9-10.2)$ \\
\hline Colon and Rectum & $62(59-65)$ & $7.6(4.8-10.4)$ & $59(57-61)$ & $8.1(6.2-10.0)$ & $58(57-60)$ & $8.5(7.1-10.0)$ & $53(52-55)$ & $9.2(7.9-10.5)$ \\
\hline Corpus uteri & $81(75-86)$ & $6.8(0.3-13.3)$ & 77 (73-79) & $8.4(5.0-11.8)$ & $75(73-77)$ & $8.8(6.5-11.1)$ & $63(60-65)$ & $10.9(8.8-13.0)$ \\
\hline Head and Neck & $40(33-47)$ & $12.3(8.2-16.4)$ & $\mathrm{NC}$ & $\mathrm{NC}$ & $\mathrm{NC}$ & $\mathrm{NC}$ & $\mathrm{NC}$ & $\mathrm{NC}$ \\
\hline Kidney & $79(73-84)$ & $7.9(1.1-14.6)$ & $73(68-78)$ & $9.7(5.0-14.5)$ & $68(63-72)$ & $11.4(8.7-14.1)$ & $54(49-58)$ & $12.2(9.7-14.7)$ \\
\hline Lung & $23(20-27)$ & $9.6(4.0-15.2)$ & $16(14-18)$ & $10.6(6.7-14.5)$ & $\mathrm{NC}$ & $\mathrm{NC}$ & $\mathrm{NC}$ & $\mathrm{NC}$ \\
\hline Ovary & $62(58-66)$ & $8.4(5.5-11.4)$ & $43(39-46)$ & $10.3(7.6-12.9)$ & $32(30-35)$ & $10.4(7.7-13.2)$ & $22(20-25)$ & $11.1(7.9-14.3)$ \\
\hline Rectum $^{\text {a }}$ & $62(56-67)$ & $8.5(3.8-13.2)$ & $57(53-60)$ & $9.3(6.4-12.2)$ & $59(56-61)$ & $9.1(6.8-11.4)$ & $50(48-53)$ & $10.1(7.9-12.3)$ \\
\hline Skin melanoma & $92(90-93)$ & $3.8(3.0-4.6)$ & $90(87-92)$ & $5.1(3.6-6.5)$ & $87(83-89)$ & $6.4(4.4-8.5)$ & $80(75-84)$ & $8.8(5.2-12.5)$ \\
\hline Stomach & $31(25-38)$ & $9.1(0.0-18.9)$ & $32(26-37)$ & $8.9(0.7-17.2)$ & $32(27-36)$ & $9.6(3.7-15.5)$ & $25(22-28)$ & $10.1(5.5-14.7)$ \\
\hline Thyroid & $99(98-100)$ & 0 & 99 (97-100) & 0 & 97 (94-98) & 0 & $83(76-89)$ & $9.9(7.5-12.3)$ \\
\hline Tissue sarcoma & $65(58-71)$ & $9.3(3.0-15.6)$ & $63(54-71)$ & $9.5(1.9-17.1)$ & $42(34-49)$ & $11.3(4.3-18.2)$ & $35(27-42)$ & $11.6(4.6-18.7)$ \\
\hline Tongue $^{\mathrm{a}}$ & $44(31-56)$ & $12.0(4.5-19.5)$ & $\mathrm{NC}$ & $\mathrm{NC}$ & $\mathrm{NC}$ & $\mathrm{NC}$ & $\mathrm{NC}$ & $\mathrm{NC}$ \\
\hline Vagina and Vulva & $70(57-80)$ & $10.7(3.4-17.9)$ & $61(50-71)$ & $11.4(5.5-17.4)$ & $43(34-52)$ & $12.4(7.0-17.7)$ & $38(31-45)$ & $12.4 \quad(8.2-16.6)$ \\
\hline \multicolumn{3}{|c|}{$15-54$ years } & & & \multicolumn{2}{|c|}{$55-64$ years } & \multicolumn{2}{|c|}{$65-74$ years } \\
\hline Biliary tracts & $28(21-35)$ & $7.2(0.0-17.0)$ & & & $20(16-25)$ & $7.6(0.0-16.6)$ & $13(11-16)$ & $8.1(0.4-15.9)$ \\
\hline Bladder & $46(39-54)$ & $11.8(6.1-17.5)$ & & & $44(38-51)$ & $11.9(7.0-16.8)$ & $40(35-45)$ & $12.1(8.4-15.8)$ \\
\hline Larynx & $52(41-61)$ & $13.0(8.4-17.7)$ & & & $\mathrm{NC}$ & $\mathrm{NC}$ & $\mathrm{NC}$ & $\mathrm{NC}$ \\
\hline Liver & $22(17-27)$ & $8.9(0.8-17.1)$ & & & $14(10-17)$ & $9.5(0.4-18.5)$ & $6(4-7)$ & $10.1(0.3-20.0)$ \\
\hline Oropharynx $^{a}$ & $27(21-32)$ & $12.1(6.6-17.5)$ & & & $31(24-39)$ & $11.9(5.7-18.0)$ & $25(17-34)$ & $12.1(3.5-20.7)$ \\
\hline Pancreas & $16(13-19)$ & $8.4(1.6-15.2)$ & & & $9(7-11)$ & $9.0(2.0-15.9)$ & $4(3-5)$ & $9.5(2.3-16.7)$ \\
\hline Small intestine & $52(42-61)$ & $11.2(5.6-16.7)$ & & & $46(36-55)$ & $11.4(5.4-17.5)$ & $29(21-37)$ & $12.1(5.3-18.9)$ \\
\hline
\end{tabular}

NC : No Cure; ${ }^{a}$ Cancer subsite

Table 4. Estimated values of the cure proportion (P) and time-to-cure (TTC) in women by cancer site and age at diagnosis. 


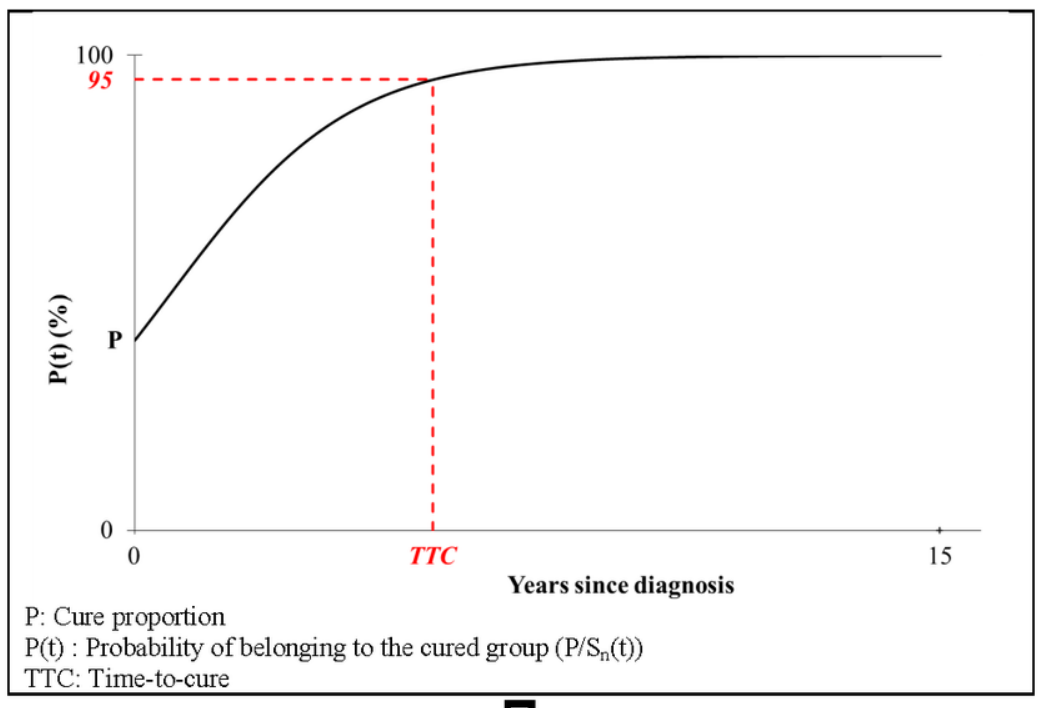

TTC: Time-to-cure

\section{Women}

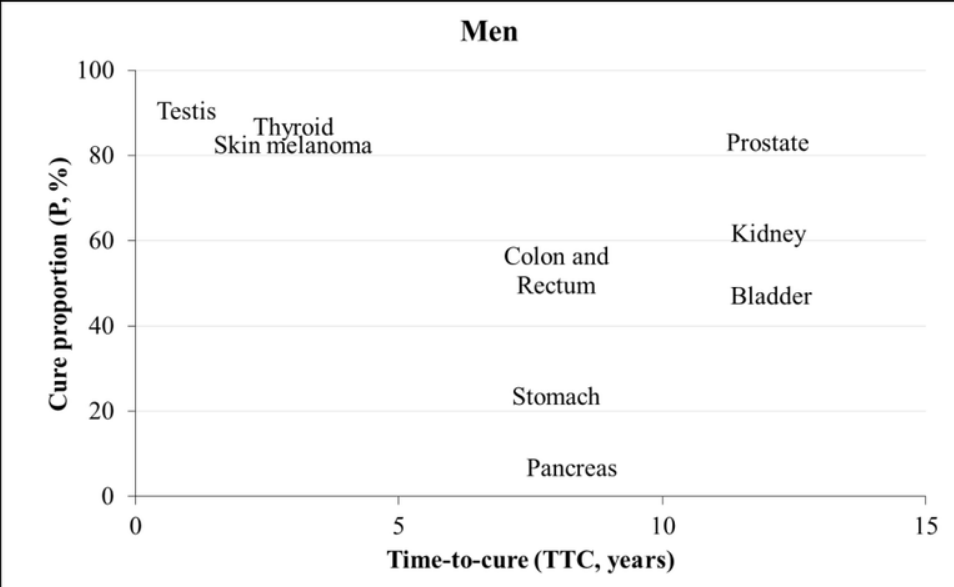

Thyroid
Skin melanoma

